\title{
Five Things an Agricultural Producer Can Do to Improve Business Profitability ${ }^{1}$
}

Edward Evans ${ }^{2}$

\section{Introduction}

The business of producing agricultural commodities is undergoing considerable change. Long gone are the days when an agricultural producer could afford to ignore what goes on outside the local area and still expect to make a profit. In today's world characterized by the increasing globalization of competition, producers must be cognizant of the world around them and must make informed decisions from an increasing volume of information. Improved financial management has become the single most important factor for success in a globally competitive market. This article summarizes five things that producers can do to improve the profitability of their agricultural businesses.

\section{Improving Record Keeping}

Information is power, and power is money. Although the idea of financial record keeping is not new, it has become increasingly essential due to global competition and narrowing profit margins. Often there is a thin line between profitable and unprofitable enterprises. To be profitable, decisions must be based on credible documented information. Computers and financial software programs such as Quicken have greatly simplified record keeping (Brooks, 2005). In addition, financial software programs are time-saving, user friendly, and can be used for all kinds of financial records, ranging from simple bookkeeping activities (balancing checkbooks, tracking employees, and creating payroll reports) to complex financial analyses (generating whole farm budgets from historic data or current data, creating transaction reports, and summarizing accounting data such as balance sheets and tax reports). For these reasons, producers should purchase computers and financial record keeping software programs.

\section{Conducting Financial Analyses}

While good financial record keeping is important, it does not guarantee profitability. A more important criterion is analyzing the recorded information based on balance sheets, income statements, and cash flow statements. Analyzing the components of these three financial statements and their interrelationships help producers understand

1. This is EDIS document FE569, a publication of the Department of Food and Resource Economics, Florida Cooperative Extension Service, Institute of Food and Agricultural Sciences, University of Florida, Gainesville, FL. Published August 2005. Please visit the EDIS website at http://edis.ifas.ufl.edu.

2. Edward Evans, Assistant Professor, Department of Food and Resource Economics, Tropical Research and Education Center, Homestead, FL, Florida Cooperative Extension Service, Institute of Food and Agricultural Sciences, University of Florida, Gainesville, FL.

The use of trade names in this publication is solely for the purpose of providing specific information. UF/IFAS does not guarantee or warranty the products named, and references to them in this publication does not signify our approval to the exclusion of other products of suitable composition. 
how well their businesses are doing and provide insights into actual or potential trouble areas. For example, a cash flow statement analysis identifies likely periods of insufficient or surplus cash, and provides useful information for working with lenders and planning repayment schedules. A balance sheet analysis identifies the net worth of a business (i.e., how much of the business is owned by the producer) and provides information for estate planning and risk taking. An income statement analysis identifies whether a business is profitable, and the sources of profits. A financial statement analysis should be conducted at least annually, and preferably quarterly.

\section{Controlling Costs}

One reason an agricultural business might be unprofitable is expensive production costs. This typically is the case when revenues are high and income is low. By tracking income and spending through the use of financial record keeping and examining the income and cash flow statements one may be able to identify the problem and take remedial action (Table 1). For example, business records can be studied to see if inputs are being purchased at competitive rates or are being fully utilized. In addition, one should always consult with local extension agents to assist with identifying lower-cost production technologies.

\section{Increasing Returns}

Another reason why an agricultural business might be unprofitable could be due to low revenues. Increasing operational scale or using improved technologies, such as higher yielding varieties, can increase gross revenue and net income; however, care must be taken to ensure that their costs do not outweigh their benefits (see EDIS document FE565, Marginal Analysis, http://edis.ifas.ufl.edu/FE565). Other ways to increase returns include direct marketing, adding value, using niche or specialty markets, and improving product quality.

Direct marketing has become popular among small producers due to advances in information technologies and consumer concerns about personal health, the environment, and food safety. Direct marketing includes community-supported agriculture
(CSA), catalog and Internet sales, and local markets (Macher, 1999; see also EDIS FE497, Six Ways to Improve the Profitability of Lychee in South Florida, http://edis.ifas.ufl.edu/FE497).

Adding value means changing a product from its raw form into a form more convenient for consumer consumption. For example, sliced pineapple adds value to the raw fruit. Other examples of adding value to fruits include jams, wines, barbecue sauces, ice cream, dried fruits, vinegars, and chocolate-dipped fruits.

Niche or specialty markets can be profitable for small operations. Large businesses cater mainly to the largest, most profitable market segments and often ignore smaller, specialty market segments, which can command premium prices.

Improving quality seems obvious, but it involves improving both the physical appearance of the good and production conditions (i.e., humane treatment of production animals, and protecting/preserving natural resources and the environment).

\section{Mixing Enterprises}

In today's economy, producers must constantly assess their enterprises so that unprofitable ones can be eliminated and profitable ones can be expanded or introduced into the market. While economic principles suggest specializing to maximize profits, global competition and increased risks encourage, especially in the case of the small farmer, choosing a mix of profitable enterprises. Diversity in enterprises can provide economic stability. When considering adding new enterprises to the existing mix the following should be undertaken:

- Determine marketability (i.e., is there a market for the product or product demand?).

- Set goals for the enterprise.

- Determine the necessary skills for making an enterprise profitable.

- Determine the availability of required facilities, equipment, and resources. 
- Create investment guidelines (i.e., how much can be invested annually and how long you can afford to wait before inflow exceeds outflow).

- Create enterprise budgets, including profit-to-yield sensitivity and price variability.

- Avoid adding enterprises that compete for the same resources (Doyle, 2004).

It should be noted that shifting from one enterprise to another can increase risks (production, financial, and marketing), so proper planning is essential.

\section{Concluding Remarks}

As globalization continues, with countries embracing open trade policies and governments reducing domestic support to producers, maintaining business profitability becomes more uncertain. This article identifies five things that producers can do to increase profitability and improve business management. Business survival is increasingly dependent on producers developing better management and analytical skills.

\section{References}

Brooks, K. 2005. Quicken for Farm

Producers-2005.

http://www.farmdoc.uiuc.edu/manage/quicken/ quicken.html.

Doyle, D. 2004. Evaluating Options for Change. Oklahoma Cooperative Extension Publication F-208. Oklahoma State University, Stillwater, OK. http://pods.dasnr.okstate.edu/docushare/.

Macher, R. 1999 Making Your Small Farm Profitable. North Adams, MA: Storey Publishing. 
Table 1. Identifying problems and taking action.

\begin{tabular}{|c|c|}
\hline Problem & Action Taken \\
\hline - High land costs & - Lease or rent land \\
\hline - High rental rates & - Renegotiate rental rates \\
\hline - High interest payments & - Renegotiate interest loan rates \\
\hline - High labor costs & - Replace hand labor with machinery \\
\hline - High machinery costs & - Use custom hiring or lease machinery \\
\hline - High repair/maintenance costs & - Sell or replace old machinery/equipment \\
\hline - High input costs & - Join with others to buy in bulk at discounted prices \\
\hline - High energy bills & - Use cost-efficient machinery/alternative energy sources \\
\hline
\end{tabular}

